\title{
Partial replacement of rice with tapioca in poor rice diets
}

The effect on growth and liver structure in the albino rat

\author{
BY S. SRIRAMACHARI, V. RAMALINGASWAMI \\ AND V. N. PATWARDHAN \\ Nutrition Research Laboratories, Indian Council of Medical Research, \\ Coonoor, South India
}

(Received I9 February 1957-Revised 8 May 1957)

In certain parts of India tapioca is used as a staple article of food by the poorer sections of the community. The ease of its cultivation and high yield/acre have helped people to meet at least their minimum calorie requirements during periods of famine. Its admittedly low protein content and the prevalence of nutritional disorders and liver disease in communities subsisting wholly on tapioca have been the subject of comment by several investigators (Johnson, 1943; Culwick, 1950). Interest in the problem was revived by the observations of Murthy, Swaminathan \& Subrahmanyan (1950) that replacing $25 \%$ of rice with tapioca in 'poor rice diets' increased growth rate of young growing rats. Subrahmanyan, Murthy \& Swaminathan (I954) subsequently confirmed these findings. Since reliance merely on the growth response might be inadequate for complete assessment of such replacement, the problem was reinvestigated in these laboratories with a threefold object: (I) studying the growth response of rats after replacement of $25 \%$ rice with tapioca; (2) investigating the cause for the apparent growth response, if confirmed, and (3) assessing the histological changes in the livers of rats fed on such diets for long periods of time.

\section{EXPERIMENTAL}

A total of 192 young growing rats from our stock colony was used in the three experiments of this investigation. In each of these, litter-mates were distributed equally between the different groups. The diets were identical with those employed by Murthy et al. (1950). Early in the course of the first experiment, it was realized that the rice-tapioca diet (diet 2) contained more calcium than the rice $\operatorname{diet}(\operatorname{diet} \mathrm{x}$ ). Hence, in subsequent experiments (nos. 2 and 3 ) an additional group of animals was maintained on a calcium-supplemented rice $\operatorname{diet}(\operatorname{diet} 3)$ with a calcium content equal to that of diet 2 .

In all the experiments daily food intake was recorded and the animals were weighed at weekly intervals throughout the first 2 months. Batches of animals from each group were killed at intervals (varying from 2 to 6 months) and the livers were examined histologically. Exp. 3, involving I 44 animals, lasted for 2 years. As well as confirming the earlier observations, we attempted to study the possible late sequelae of histological changes in the liver. All samples of the livers were fixed in $4 \%$ formaldehyde 
and processed through paraffin as well as carbowax and the sections were stained with haematoxylin and eosin, Sudan IV, Toluidine Blue and Periodic Acid Schiff, as described by us earlier (Sriramachari \& Ramalingaswami, 1952).

\section{RESULTS}

Growth rate. Table I shows the mean daily food intake/rat and the mean weekly growth rate, calculated over the first 8 weeks, of animals maintained on the different diets. It was clear that the growth rates on rice (diet 1 ), rice-tapioca (diet 2 ) and ricecalcium (diet 3 ) in each of the experiments followed the same pattern. Differences of the growth response in the three experiments might be attributable to the differences between the samples of rice used. In fact, Subrahmanyan, Kuppuswamy \& Swaminathan (I954) have observed large variations in the growth rates of rats with different samples of rice. However, it may be emphasized that only one batch of rice was used during the whole period of active growth in any single experiment. Statistical analysis (Table I) showed that the differences in the growth rates of rats on the three diets in each experiment were highly significant.

Table I. Mean food intake and growth rates of rats on the different diets

\begin{tabular}{|c|c|c|c|c|}
\hline $\begin{array}{l}\text { Particulars of experiment } \\
\text { and diet }\end{array}$ & $\begin{array}{l}\text { No. of } \\
\text { animals }\end{array}$ & $\begin{array}{l}\text { Mean food } \\
\text { intake } \\
\text { (g) }\end{array}$ & $\begin{array}{l}\text { Mean gain in } \\
\text { weight/week } \\
(\mathrm{g})\end{array}$ & $\begin{array}{c}\text { Standard error } \\
\text { of the difference } \\
\text { between two } \\
\text { means }\end{array}$ \\
\hline \multicolumn{5}{|l|}{ Exp. $x$} \\
\hline Rice $\operatorname{diet}(\mathbf{I})$ & 12 & $15 \cdot 1$ & $5 \cdot 37\}$ & \multirow[b]{2}{*}{0.35} \\
\hline Rice-tapioca diet (2) & 12 & $16 \cdot 1$ & $6 \cdot 55\}$ & \\
\hline \multicolumn{5}{|l|}{ Exp. 2} \\
\hline Rice $\operatorname{diet}(\mathrm{I})$ & 8 & $9^{\cdot} \mathrm{I}$ & $2 \cdot 35$ & \multirow{3}{*}{0.52} \\
\hline Rice-tapioca diet (2) & 8 & $10 \cdot 7$ & $3 \cdot 19\}$ & \\
\hline Rice diet + calcium (3) & 8 & 10.8 & $4 \cdot 8 \mathrm{I}$ & \\
\hline \multicolumn{5}{|l|}{ Exp. 3} \\
\hline Rice $\operatorname{diet}(\mathrm{I})$ & 48 & $8 \cdot 2$ & $3.07)$ & \multirow{3}{*}{$0.3 \mathrm{I}$} \\
\hline Rice-tapioca diet (2) & 48 & $9 \cdot 7$ & 4.82 & \\
\hline Rice diet + calcium (3) & 48 & $9 \cdot 7$ & $7 \cdot 22)$ & \\
\hline
\end{tabular}

Mortality rate. In Exp. 3 , in which a large number of animals was employed over a period of 2 years, some of the animals died at various times in the course of the investigation. Before 22 months were over, fifteen animals fed on the rice diet and thirteen animals on the rice-tapioca diet died, whereas only three animals died in the group fed on the rice-calcium diet. Histologically the livers of animals that died were not appreciably different from those of other animals in the corresponding group at any given period.

Histological changes in the liver. Histological examination was done of livers of all surviving animals in groups fed on rice (diet I) and rice-tapioca (diet 2) and of thirty-nine animals in groups fed on the rice-calcium diet. In all three experiments the same trends were observed, with slight variations in the time of onset of severe lesions. Histologically the livers in all the groups showed a mild to moderate degree of parenchymal damage of the protein-deficiency type (Pl. I). The liver cells were characterized 
by a reduction in cytoplasmic protein and more particularly in ribonucleoprotein content. Various degrees of liver-cell swelling and cytoplasmic vacuolation, of the protein-deficiency type, were observed. In a few specimens, typical plant-cell-like appearances were encountered. Very little fatty change was observed in the carbowax sections stained with Sudan IV. More severe forms of liver-cell damage, such as focal necrosis of liver cells, were absent throughout the whole investigation. These changes are in accordance with our earlier experience with low-protein diets (Ramalingaswami, Sriramachari \& Patwardhan, I954).

As already mentioned, severe lesions developed at different times in each experiment. Thus, in Exp. I fairly advanced liver-cell damage of the protein-deficiency type was noticed at the end of $9 \frac{1}{2}$ months, and in Exp. 2 a nearly similar picture was seen by about 4 months. In Exp. 3 the same intensity of lesions was not observed until as late as 18 months. These differences could be attributed to the variations observed in food intake and in initial growth rates in each experiment.

There was no further accentuation with time of the histological changes in the liver. In fact, by the end of 24 months, many of the livers showed only milder degrees of parenchymal damage. Probably adaptive mechanisms had come into operation. Mesenchymal activity was not observed in any of the liver specimens at any stage of the experiments.

\section{Table 2. Severity of the protein-deficiency type of liver-cell damage* produced} in the rats on the different diets in each experiment

\begin{tabular}{|c|c|c|c|c|c|c|}
\hline \multirow{2}{*}{$\begin{array}{l}\text { Exp. } \\
\text { no. }\end{array}$} & \multirow[b]{2}{*}{ Diet } & \multirow{2}{*}{$\begin{array}{c}\text { No. of } \\
\text { animals }\end{array}$} & \multirow{2}{*}{$\begin{array}{c}\text { No. of } \\
\text { normal } \\
\text { livers }\end{array}$} & \multicolumn{3}{|c|}{ No. of livers showing damage } \\
\hline & & & & Mild & Moderate & Severe \\
\hline \multirow[t]{2}{*}{ I } & Rice (I) & 12 & 4 & 8 & Nil & Nil \\
\hline & Rice-tapioca (2) & 12 & I & 4 & 5 & 2 \\
\hline \multirow[t]{3}{*}{2} & Rice (I) & 8 & Nil & Nil & 8 & Nil \\
\hline & Rice-tapioca (2) & 8 & Nil & 2 & $\mathrm{Nil}$ & 6 \\
\hline & Rice + calcium (3) & 8 & 6 & 2 & Nil & Nil \\
\hline \multirow[t]{3}{*}{3} & Rice (1) & 33 & 13 & 18 & 2 & Nil \\
\hline & Rice-tapioca (z) & 35 & 3 & $x 8$ & II & 3 \\
\hline & Rice + calcium (3) & 39 & I3 & $\mathbf{2 3}$ & 2 & $\mathbf{I}$ \\
\hline
\end{tabular}

Between the livers of the animals on the three different diets, there were perceptible differences in the severity of damage at almost all periods of histological examination (Table 2). The livers of the animals on the rice-tapioca diet showed the proteindeficiency type of histological changes more often and somewhat more extensively, which might be expected to follow the lowering of protein content by partial replacement of rice with tapioca. More striking was the remarkable improvement in the histological picture of animals maintained on the rice-calcium diet (diet 3 ). Here only mild changes were observed in the earlier periods, and thereafter the livers were almost normal until the end of the experimental period. 


\section{DISCUSSION}

The results of these experiments indicate that partial replacement of rice with tapioca promotes improved growth of rats, as reported by Subrahmanyan, Murthy \& Swaminathan (1954). In terms of growth performance, the higher calcium content of tapioca would appear to mitigate the ill effects of the further reduction in protein content resulting from partial replacement of rice with tapioca. In spite of this, such partial replacement appears to have other deleterious effects, particularly that of accentuating the protein-deficiency type of liver damage associated with poor rice diets.

Supplementing the rice diet with calcium (diet 3 ) produced an overall improvement in the rats. There was a much more satisfactory growth rate than even with the ricetapioca diet (diet 2). This finding is in accordance with the observation of several investigators (Aykroyd \& Krishnan, I937; Van Duyne, Lanford, Toepfer \& Sherman, 1941; Sherman, Campbell \& Ragan, 1949; Anonymous, 1950; Wooley \& Mickelsen, 1954). Of greater significance was the fact that such calcium supplementation even corrected the histological changes in the liver produced by the low protein content of the rice diet (diet $\mathbf{I}$ ). There was considerable improvement even in mortality rate.

The overall beneficial effect of a higher level of calcium in promoting better growth, lowering the mortality rate and even correcting the histological changes in the liver appears to be of more than academic interest. Although Aykroyd \& Krishnan (1938) have demonstrated the beneficial effect of a calcium supplement to the "poor rice diet', the modus operandi is not known. It was not possible to explain all the beneficial effects observed in our investigation merely on the basis of increased retention of ingested calcium, which was only of the order of a few $\mathrm{mg}$ for every $100 \mathrm{~g}$ of diet, nor does the level of calcium appear to influence nitrogen balance (Swaminathan, 1939; Henry, Kon \& Thompson, I940). Actually Subrahmanyan, Murthy \& Swaminathan (1954) observed that nitrogen metabolism was not significantly altered in rats fed ad lib. on a rice-tapioca diet. Probably the level of calcium has some yet unexplained effect on the utilization of dietary protein, which perhaps cannot be detected by short-term nitrogen-balance studies. Until a more precise knowledge of the relationship between the level of dietary calcium and protein metabolism is known, it is difficult to explain the overall beneficial effect of supplementing a 'poor rice diet' with calcium.

\section{SUMMARY}

I. In earlier work partial ( $25 \%$ ) replacement of rice with tapioca flour in 'poor rice diets' was found to improve the growth response of rats. However, the cause of the apparent growth response or the possible histological changes in the liver were not studied.

2. In the present investigation comprising three experiments, a total of 192 young growing rats was maintained for prolonged periods on the rice diet, the rice-tapioca diet, and a calcium-supplemented rice diet. Growth performance of the rats during the first 2 months of each experiment confirmed the earlier observation that partial replacement with tapioca caused better growth. The higher calcium content of tapioca 
is probably responsible for this effect. 'The addition of an equivalent amount of calcium to the rice diet caused a much better growth rate.

3. The long-term study clearly indicated that even partial replacement of rice by tapioca accentuates the protein-deficiency type of liver damage seen with 'poor rice diets', which could be due to a further reduction in the protein content of the diet.

4. A slight increase in the calcium content of 'isoprotein dietaries' has an overall beneficial effect on the liver picture of animals receiving 'poor rice diets'.

5. The exact mechanism by which calcium exerts its beneficial effect on protein metabolism is not at present clear.

We wish to thank Mr A. D. Tasker, M.Sc., Ph.D., for the statistical analysis of the data. Our thanks are due to Mr Maria Susai for his technical help in carrying out this investigation.

\section{REFERENCES}

Anonymous (1950). Nutr. Rev. 8, 229.

Aykroyd, W. R. \& Krishnan, B. G. (1937). Indian Y. med. Res. 25, 367.

Aykroyd, W. R. \& Krishnan, B. G. (1938). Lancet, 235, 153.

Culwick, G. M. (1950). Dietary Survey among the Zande of the South Western Sudan, p. 73. Khartoum: Agricultural Publications Committee.

Henry, K. M., Kon, S. K. \& Thompson, S. Y. (1940). Biochem. F. 34, 998.

Johnson, A. S. (1943). Indian med. Gaz. 78, 227.

Murthy, H. B. N., Swaminathan, M. \& Subrahmanyan, V. (1950). F. sci. indust. Res. 98 , 173.

Ramalingaswami, V., Sriramachari, S. \& Patwardhan, V. N. (1954). Indian 7. med. Sci. 8, 434.

Sherman, H. C., Campbell, H. L. \& Ragan, M. S. (1949). F. Nutr. 37, 317.

Sriramachari, S. \& Ramalingaswami, V. (1952). F. clin. Path. 5, 345.

Subrahmanyan, V., Kuppuswamy, S. \& Swaminathan, M. (1954). Bull. cent. Fd tech. Res. Inst. 3, 272.

Subrahmanyan, V., Murthy, H. B. N. \& Swaminathan, M. (1954). Brit. F. Nutr. 8, x.

Swaminathan, M. (1939). Indian $\mathcal{F}$. med. Res. 27, $x_{47}$.

Van Duyne, F. O., Lanford, C. S., Toepfer, E. W. \& Sherman, H. C. (194I). F. Nutr. 2 I, 22 I.

Wooley, J. G. \& Mickelsen, O. (1954). F. Nutr. 52, 59 1.

\section{EXPLANATION OF PLATE}

I. Section of liver of a normal stock rat. Stained with haematoxylin and eosin. $\times 75$.

2. Section of liver of a rat from rice group (diet $\mathrm{I}$ ) killed after $9 \frac{1}{2}$ months. Mild vacuolation of liver cells. Stained with haematoxylin and eosin. $\times 75$.

3. Section of liver of a rat from rice-tapioca group (diet 2 ) killed after $9 \frac{1}{2}$ months. Severe generalized vacuolation of liver cells. Stained with haematoxylin and eosin. $\times 75$.

4. Section of liver of a rat from rice group (diet $\mathrm{I}$ ) killed after $\mathrm{I} 2$ months. Mild generalized cytoplasmic vacuolation. Stained with haematoxylin and eosin. $\times 90$.

5. Section of liver of a rat from rice--tapioca group (diet 2 ) killed after 12 months. More severe generalized cytoplasmic vacuolation. Stained with haematoxylin and eosin. $\times 90$.

6. Section of liver of a rat from rice-calcium group (diet 3 ) killed after 12 months. Moderate cytoplasmic vacuolation confined to small focal areas, the rest of the parenchyma is apparently normal. Stained with haematoxylin and eosin. $\times 90$. 

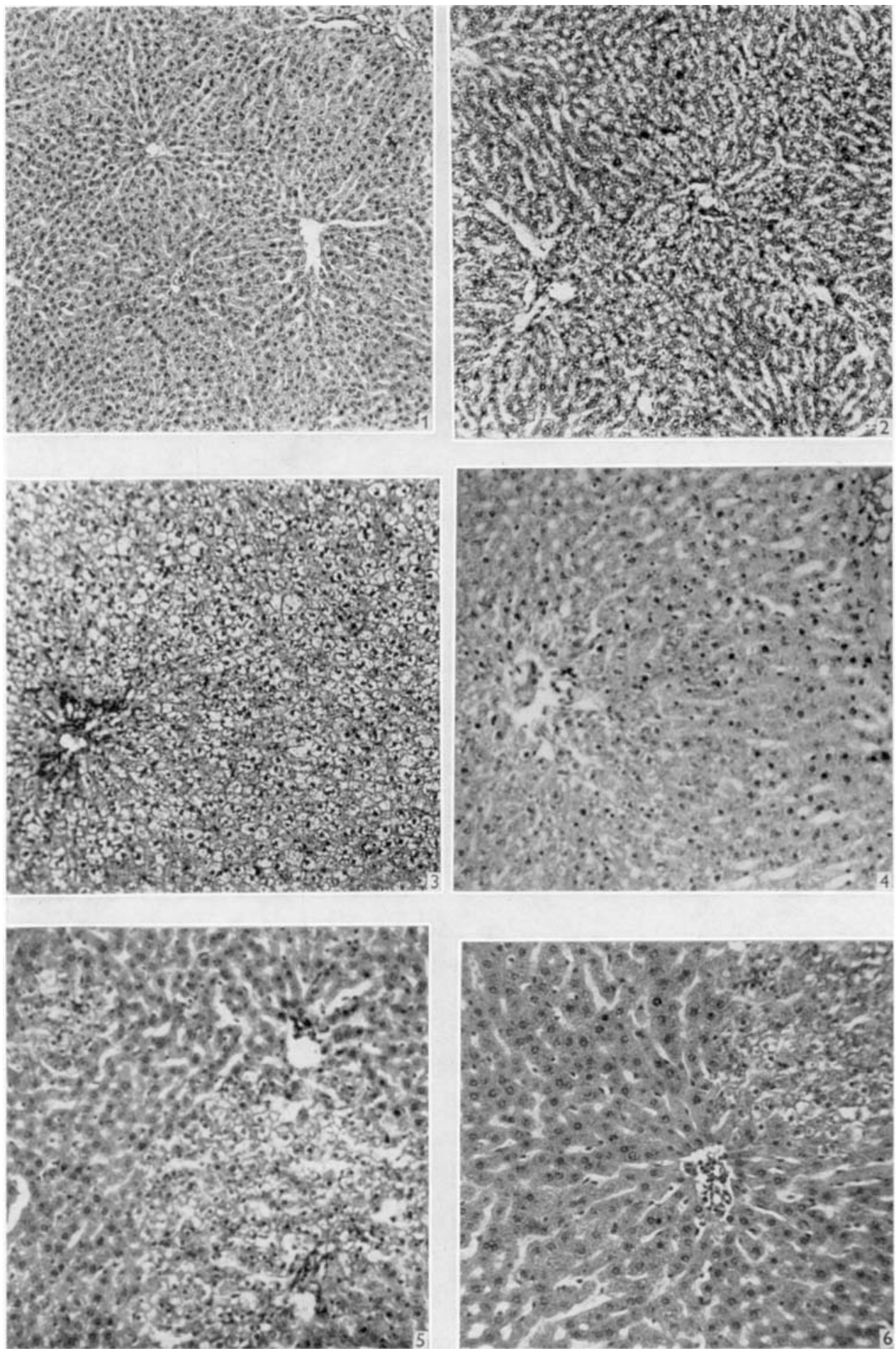

British fournal of Nutrition, Vol. I2, No. I

(Facing p. 12) 